\title{
生産性向上に向けた建築作業者の動作手順評価に関する研究
}

\section{ACTIVITY PROCESS ANALYZATION OF CONSTRUCTION WORKERS}

\author{
石 岡宏晃* \\ Hiroaki ISHIOKA
}

\begin{abstract}
The author demonstrated a new evaluation method of construction workers' activity sequence.
Firstly the author described the importance of transportation by the comparison between factory and construction site. Then the author classified the worker action into nine categories, which are 'Insert', 'Remove', 'Arts', 'Walk', 'Get', 'Carry', 'Place', 'Stay', and 'KAKUNIN', based on the change of condition (e.g. rotation, position, shape, and finishing). Secondly the author explained 'Action Array' which is based on the method of genetics. Thirdly the author explained the flow of calculation which reveals the 'Smoothness' of Action Array and 'Similarity' between pairs of Action Array. Finally the author verified the method by test calculation using sample data which was captured in the experimental construction of scaffoldings.
\end{abstract}

Keymords: Workstudy, Construction worker, Sequenceanalysis, Productivity, Adtion array

作業研究，建築作業者，手順分析，生産性，動作配列

\section{1. 緒言}

建築現場の運営においては，日々の作業が滞りなく進捗するよう 計画の調整と作業の管理がおこなわれる。作業の進捗は，資材供給 のタイミングやその作業日における配置計画など，その時々の作業 環境に影響を受けている。建築作業者はその時々の作業環境に応じ て柔軟に動作手順を調整しているため，より効果的な計画の調整す なわち “改善”を実施するためには，動作手順の実態を把握し改善 の着眼点を得ることが重要である。

現在の現場実務においては, 完成された施工数量を, その完成に 要した投入人工 [人日］で除算した“歩掛り”という数值を作業の 進捗の評価基準としている。この歩掛りは，日々の投入人工をその 根拠としており，すなわち主体作業・付帯作業・余裕・非作業，の すべてを含めた全作業注 1) に対寸る数值である。そのため，具体的 に資材配置や動作手順を改善する際には，現場管理者あるいは施工 実施者の主観を頼りにする以外に方法がないのが現状である。

著者は定量的な建築作業の把握に向け，既報 ${ }^{1)}$ において建築作業 者の動作データを記録する作業測定のシステムを構築するなど，新 しい作業分析の手法構築に向けた取り組みを進めている。なお，本 研究は建築作業者が 1 名あるいは 2 名程度で運搬可能な寸法および 重量の部材を取り扱う作業を考察の対象としている。
本論では，動作手順の実態を把握し改善の着眼点を得ることを目 的として建築作業者の動作手順評価手法を提案し, 枠組足場施工実 験において検証した。

本論の構成を示す。 2 章では作業分析に関係する既往研究を紹介 し，これまでに実施された作業分析研究を振り返る。3 章では建築 作業における動作の特徵と運搬動作の重要性を述べ, 本研究におけ る動作分類を示す。 4 章では動作を記録する手法について, 動作分 類を配列として記録する手法を示す。5 章では本研究における手順 の評価值として位置付ける “円滑度”と“類似度”について，その 計算方法を示す。6 章では, 施工実験のデータを用いた円滑度と類 似度の計算結果と考察を示寸。

\section{2. 既往の研究}

建築現場内における建築作業者の作業分析に関寸る研究は，田村 $ら^{2)}$ による研究をはじめとして種々の取り組みが進められており, 1990 年にはそれまでに実施されてきた研究開発の内容を集め, 日本 建築学会から「作業能率測定指針 ${ }^{3)} 」 と し て$ 作業測定の手法が網羅 的に取りまとめられている。同指針において単位動作レベルで測定 をおこなう手法は，時間研究として標準時間の設定を主眼に置いた 手法が示されているが, 手順の定量的な評価手法は示されていない。

\footnotetext{
* 清水建設侏技術研究所 建修
} Institute of Technology, SHIMIZU Corp., M.Arch. 
単位動作をその手順と併せて取り扱う手法として, 製造業におい て発展した標準時間設定法である MOST ${ }^{4}$ ) (Maynard Operation Sequence Technique) がある。江口ら ${ }^{5)}$ は MaxiMOST 注2) 分析を 建築作業に応用し, 得られた標準時間を実績值と比較することで, 工具使用のように規則的な作業では MOST 分析值は実績值とよく 近似するが，小運搬や調整のような不規則な作業では実態との差異 が生じやすいという課題を明らかにした。

工程分析の報告例として, 三根ら ${ }^{6)}$ は内装・設備工事の䌕まり工 程を明らかにするとともに同工事内の 4 つの単位工程を明らかにし， 建築工事に工程分析を適用寸るうえでの課題として，製造業に比心゙ て作業者の動きの多い建築作業では，作業者の移動を旨く表現でき ない点を指摘している。

近年でも, 志手ら ${ }^{7)}$ による高層集合住宅における揚重作業の調査 事例や，蟹澤・権藤ら ${ }^{8 ）}$ 9) による工業化工法住宅の施工現場にお ける作業測定と改善の事例など，現地に測定員を配置した測定は実 施されているものの，その評価は測定員の主観，あるいは所要時間 や実施回数による従来の評価手法を用いている。

上記の通り，作業測定結果を評価する上での手順や小運搬などの 取り扱いは依然として明確になっていない。

\section{3、建築作業における動作}

\section{1 建築作業の特徵}

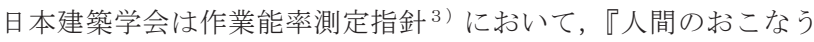
動作は（中略） 17 種類の基本的な動作単位（Therblig：サーブリッ グという）から構成される』としたうえで，サーブリッグ記号が製 造業主体で定義されているため『姿勢などの全身体的変化を伴う建 築作業に対する動作分析にはなじみにくい面がある。』と指摘してい る。そのうえで,『状況に応じて, 新たな動作単位を追加』すること を推奨し，田村ら 10）の提案した追加記号を例示している。

田村ら 10) は『建築作業は工場作業に比較して, 総合的, 組立生 産であり，しかも注文生産であることが多い。従って一定の進行的 生産過程が同位置で一定の周期をもって繰り返されることがない。』 と指摘したうえで，サーブリッグ記号と建築作業の要素の比較の中 で “作業姿勢”之 “身体移動”に関する不足を補うための追加記号 を定義している。この指摘は，建築物という製品が現地一品生産か つヒトを包含する大寸法を持つという特徴が変化していないことか ら, 今日の建築作業における動作においても継続して当てはまる。

\section{2 建築作業における部材の状態変化}

前述した田村らの指摘のとおり，建築作業は一定のプロセスを同 位置で繰り返すことがない。しかしながら，同位置での実施という 観点を除けば，規格化された標準品である部材を取り付ける繰り返 し作業であるという点においては，建築物も電化製品等の製造業に おける生産物と同様である。建築作業者の動作研究をおこなう上で は, 動作が同位置で繰り返されないという特徴がデータ上でどのよ うに顕出するのかを分析する必要がある。

既往の工程分析においては, JIS の工程図記号（JIS_Z_8206）を 用いて，作業を加工・運搬・停滞・検査の 4 つの大分類で捉えるこ ととしている ${ }^{3)}$ 。これらは製品の状態変化に着目して定義されてお り, 位置変化は全て運搬として単純化されている。その他, 製品の 形状変化あるいは性質変化を加工，変化がない状態を停滞，合否評
価の変化を検査とする分類である。

著者は繰り返し位置の変化が与える影響の把握に向けて, 建築作 業者の状態変化に着目した状態変化の図化を試みた。部材の状態変 化を, 位置変化・姿勢変化・形状変化と捉えて考察し, 得られた結 果を図 1 に示す。なお, 本研究は, 作業実施スペース全体を俯瞰で きる程度に距離を設けた測定を想定しており, 主として建築作業者 と同等程度あるいは同等以上の寸法を持った部材を対象とする。微 小部品（例えばネジや釘）の状態変化を対象とはしていない。

横軸には部材の時系列の姿勢変化を左から右へ示し, 荷姿・保管 姿勢・運搬姿勢・加工姿勢・完成姿勢の 5 種の姿勢をとると捉えた。 縦軸には部材の時系列の位置変化を示し, 現場外 - 貯蔵位置 - 加工 位置・完成位置の 4 種の位置をとると捉えるとともに，それらの間 には位置変化の軌跡である運搬経路が存在すると捉える。

形状変化は加工によってのみ発生する変化であり, 図中には搬入 時の形状の部材を灰色で示し, 加工によって形状変化した部材を黒 色で示した。図は左下から右上に向かった時系列を示す。

前述した位置・姿勢が定義されるタイミングについて考察する。 完成位置と完成姿勢は部材個別のパラメータであり，これは設計 図（あるいは施工図）において規定すべき属性である。また加工姿 勢・運搬姿勢・保管姿勢に関しては, その部材の形状・寸法によっ てパターン分け出来る属性と考える。さらに加工位置・貯蔵位置に 関しては, 現場内の配置計画や搬入計画によって規定される属性で あるため, これら計画情報との連携が必要となると考えられる。

運搬経路は, 運搬の終着点である完成位置と, 運搬の始発点であ る貯蔵位置との 2 点が事前に決まっていても, 併行作業の影響を受 けて時々刻々変化するという点に注意する必要がある。

さらに図中で着目すべきは，荷姿において複数の部材がまとまっ た状態にあるという点である。図中の中央の四角は, 荷姿からまと まりを解かれた個々の部材に対して繰り返し実施される動作を示し ており，運搬という工程を処理する実施主体の能力に応じてまとま りとなる数量が変化し, 繰り返しプロセスの回数が変化する点を考 慮する必要があると言える。

以上の考察から，一定のプロセスを同位置で繰り返すことがない という建築作業の特徴は，位置変化プロセスと姿勢変化プロセスと を含んだ “運搬作業”を分析することにより定量的に明らかになる と著者は捉えた。

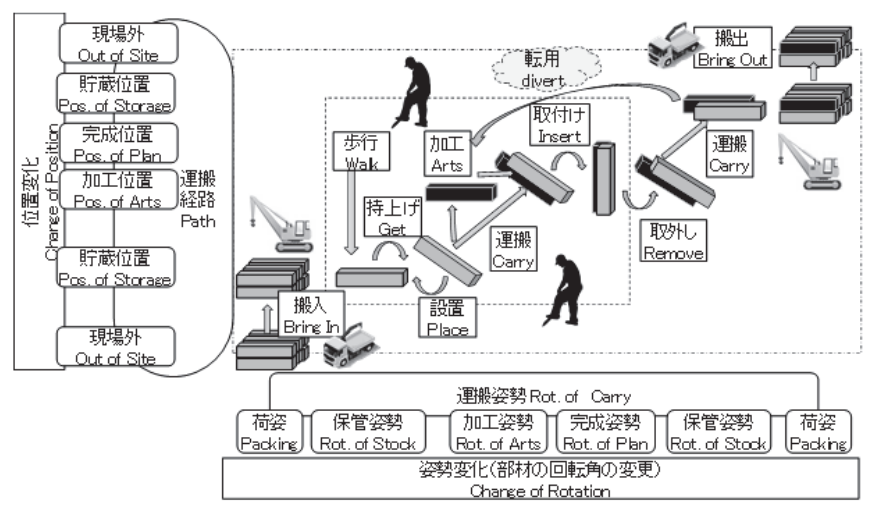

Fig. 1 The process of change of state 


\section{3 動作の分類}

建築作業者の運搬動作の変化を捉えることを目的として, 本研究 における動作分類を検討する。前述した部材の状態変化の考察を踏 まえて，既往の工程図記号とリンクさせたかたちで，建築作業者の 状態変化を根拠とした建築作業者単体における動作分類を表 1 に示 す 9 分類として定義した。

Table1 Category of Worker's Action

\begin{tabular}{|c|c|c|c|c|c|c|}
\hline \multicolumn{3}{|c|}{$\begin{array}{l}\text { classification in this paper } \\
\text { 本論文における動作分類 }\end{array}$} & \multicolumn{4}{|c|}{$\begin{array}{c}\text { classification in JIS Z8206 } \\
\text { JIS Z8206 の分類 }\end{array}$} \\
\hline & \multirow[b]{2}{*}{$\begin{array}{l}\text { Category } \\
\text { of Action } \\
\text { 動作分類 }\end{array}$} & \multicolumn{2}{|c|}{$\begin{array}{c}\text { Change of State } \\
\text { 状態変化 }\end{array}$} & \multirow[b]{2}{*}{$\begin{array}{l}\text { Sym- } \\
\text { bol } \\
\text { 記号 }\end{array}$} & \multirow{2}{*}{$\begin{array}{c}\text { Name } \\
\text { of } \\
\text { Sym- } \\
\text { bol } \\
\text { 記号 } \\
\text { の } \\
\text { 名称 }\end{array}$} & \multirow{2}{*}{\begin{tabular}{|l} 
Ele- \\
ment \\
of \\
Pro- \\
cess \\
要素 \\
工程 \\
\end{tabular}} \\
\hline & & $\begin{array}{c}\text { (対象) } \\
\text { 運搬対象物と } \\
\text { 建築作業者 } \\
\text { focus: workers } \\
\text { and parts }\end{array}$ & $\begin{array}{c}\text { (対象) } \\
\text { 原料・材料 } \\
\text { 部品・製品 } \\
\text { focus: parts }\end{array}$ & & & \\
\hline 1 & $\begin{array}{l}\text { Insert } \\
\text { 取付け }\end{array}$ & $\begin{array}{c}\text { Parts to component } \\
\text { 部品から完成品の構成物 } \\
\text { 一変化させる動作 }\end{array}$ & \multirow{3}{*}{$\begin{array}{c}\text { Shape } \\
\text { Parameter } \\
\text { 形状変化 } \\
\text { 性質変化 }\end{array}$} & \multirow{3}{*}{$\bigcirc$} & \multirow{3}{*}{$\begin{array}{c}\text { Ope- } \\
\text { ration } \\
\text { 加工 }\end{array}$} & \multirow{3}{*}{$\begin{array}{c}\text { Ope- }^{-} \\
\text {ration } \\
\text { 加工 }\end{array}$} \\
\hline 2 & $\begin{array}{l}\text { Remove } \\
\text { 取外し }\end{array}$ & $\begin{array}{c}\text { Component to parts } \\
\text { 完成品の構成物から部品 } \\
\text { へ変化させる動作 }\end{array}$ & & & & \\
\hline 3 & $\begin{array}{l}\text { Arts } \\
\text { 加工 }\end{array}$ & \begin{tabular}{|c|} 
Shape \\
形状変化の動作
\end{tabular} & & & & \\
\hline 4 & $\begin{array}{l}\text { Walk } \\
\text { 歩行 }\end{array}$ & $\begin{array}{l}\text { 位置変化の動作 } \\
\text { (空手の移動) }\end{array}$ & \multirow{4}{*}{$\begin{array}{l}\text { Position } \\
\text { 位置変化 }\end{array}$} & \multirow{4}{*}{0} & \multirow{4}{*}{$\begin{array}{c}\text { Trans } \\
\text { port } \\
\text { 運搬 }\end{array}$} & \multirow{4}{*}{$\begin{array}{l}\text { Tran } \\
\text { port } \\
\text { 運搬 }\end{array}$} \\
\hline 5 & $\begin{array}{c}\text { Get } \\
\text { 持上げ }\end{array}$ & $\begin{array}{l}\text { 姿勢変化の動作 } \\
\text { (空手 } \rightarrow \text { 部材保持) }\end{array}$ & & & & \\
\hline 6 & $\begin{array}{l}\text { Carry } \\
\text { 運搬 }\end{array}$ & $\begin{array}{l}\text { 位置変化の動作 } \\
\text { (部材保持の移動) }\end{array}$ & & & & \\
\hline 7 & $\begin{array}{l}\text { Place } \\
\text { 設置 }\end{array}$ & $\begin{array}{l}\text { 姿勢変化の動作 } \\
\text { (部材所持 } \rightarrow \text { 空手) }\end{array}$ & & & & \\
\hline \multirow{2}{*}{8} & \multirow{2}{*}{$\begin{array}{l}\text { Stay } \\
\text { 停滞 }\end{array}$} & \multirow{2}{*}{$\begin{array}{c}\text { Nothing } \\
\text { 位置・姿勢・形状 } \\
\text { 変化なし }\end{array}$} & $\begin{array}{c}\text { Nothing } \\
\text { (as planned) } \\
\text { 変化なし } \\
\text { 計画と整合 }\end{array}$ & $\nabla$ & $\begin{array}{l}\text { Sto- } \\
\text { rage } \\
\text { 貯蔵 }\end{array}$ & \multirow{2}{*}{$\begin{array}{l}\text { Stay } \\
\text { 停滞 }\end{array}$} \\
\hline & & & $\begin{array}{c}\text { Nothing } \\
\text { (no planned) } \\
\text { 変化なし } \\
\text { 計画と不整合 }\end{array}$ & & $\begin{array}{c}\text { Delay } \\
\text { 滞留 }\end{array}$ & \\
\hline \multirow{2}{*}{9} & \multirow{2}{*}{$\begin{array}{l}\text { KAKU } \\
\text { NIN } \\
\text { 確認 }\end{array}$} & \multirow{2}{*}{$\begin{array}{c}\text { Variety check } \\
\text { (Quantity, Quality, } \\
\text { Location, Sequence, } \\
\text { Proceed, Situation) } \\
\text { 合否評価の変化 } \\
\text { (数量・品質・位置 } \\
\text { ·手順・進捗・状況) }\end{array}$} & $\begin{array}{c}\text { State of } \\
\text { Inspection } \\
\text { (Quantity) } \\
\text { 合否の変化 } \\
\text { (数量) }\end{array}$ & & \begin{tabular}{|l} 
Quan \\
-tity \\
In- $^{-}$ \\
spec- $^{-}$ \\
tion \\
数量 \\
検查 \\
\end{tabular} & \multirow{2}{*}{$\begin{array}{l}\text { In- } \\
\text { spec- } \\
\text { tion } \\
\text { 検查 }\end{array}$} \\
\hline & & & $\begin{array}{c}\text { State of } \\
\text { Inspection } \\
\text { (Quality) } \\
\text { 合否の変化 } \\
\text { (品質) }\end{array}$ & & $\begin{array}{l}\text { Qua- } \\
\text { lity } \\
\text { In- }^{-} \\
\text {spec- }^{-} \\
\text {tion } \\
\text { 品質 } \\
\text { 検査 }\end{array}$ & \\
\hline
\end{tabular}

表の左には本論における 9 種の動作分類を示し, 右には比較のた め既往の分類であるJIS_Z8206における工程分類を示した。

加工は性質変化と形状変化とを分け, 性質変化のうち部品から完 成品の構成物とする動作を重視することが建築作業における手戻り の検出には必要と考え, 取付けと取外しとして分割した。

運搬は，前述したとおり建築作業の動作では作業姿勢と身体移動 を認識すべきであり，それらの考慮が可能な要素とするため，運搬 対象物に向から動作を歩行, 運搬対象物を保持する動作を持上げ, 運搬対象物を保持して目的位置に向から動作を運搬，運搬対象物を
開放する動作を設置，として 4 つに分割した。

停滞に関しては，作業者に着目する場合には貯蔵という概念はそ ぐわないため上位要素である停滞のみとして定義した。

検査に関しては, 数量や品質に関寸る検査以外にも, 位置や手順 の計画との差異の評価や, 進捗や状況に応じた行動選択をおこなう ための種々の評価の動作を統合して, 広義に確認として定義する。

本分類においては、2 章で言及した「小運搬」は“歩行・持上げ・ 運搬・設置”を繰り返しながらその都度微小な別動作を挟むデータ として把握され、「調整」は“確認”として把握されるか, あるいは 微小な動作として “取付け”に含まれた形で把握されるものと想定 される。

本分類は建築作業者の位置変化と部材所持の有無の変化，ならび に動作の終着地点における部材の完成に着目して手順を分類してお り、各動作分類が付与された実際の作業者の動作は、それを構成す る建築作業者の四肢の変化にバリエーションがある。実際の作業者 の動作と、付与される動作分類との間の再現性は、実際の作業者の 動作を測定データとする測定手法と、得られた測定データを解釈し て動作分類を付与する分類手法とに依抛する。より正確で再現性の 高い測定手法と分類手法との検討については今後の課題としたい。

\section{4. 動作手順の表現}

\section{1 建築作業における動作手順の特徵}

田村らが他種工業との差異に『動作には環境に応じた弾力性が求 められる』と記述 10) したとおり, 建築現場という作業空間では複 数の建築作業者により複数の作業が同時並行的に実施されているた め, 建築作業者は動作中に, 実施環境に応じた調整を実施する。 すなわち, 観測される動作手順は, 並行作業に対する調整を含んだ 情報であり, 作業者自身が想定した手順とは異なる場合があるとい う点に注意すべきである。並行作業のない環境において観測された 動作手順は, 作業者自身が想定した動作手順とみなすことができる。

\section{2 動作手順の観測}

動作は建築作業者毎に観測される事象であるため, 動作手順も個 別に存在する。その観測においては時系列的な記録が望ましく, 個々 の動作が測定点間に埋没しにくい測定間隔での記録が求められる。

本研究においては, 建築現場内で実施される動作を 1 秒に 1 回の 測定により記録する。この測定間隔は, 人間の一般的な歩行周期か ら設定注3) するとともに, 建築現場内の動作に関する予備調查とし て建築現場内の作業風景の観察を実施し, 部材の持上げなどの動作 が数秒の継続時間を持つという結果を得て決定した。

1 秒間隔で記録される動作分類のイメージを図 2 に示す。

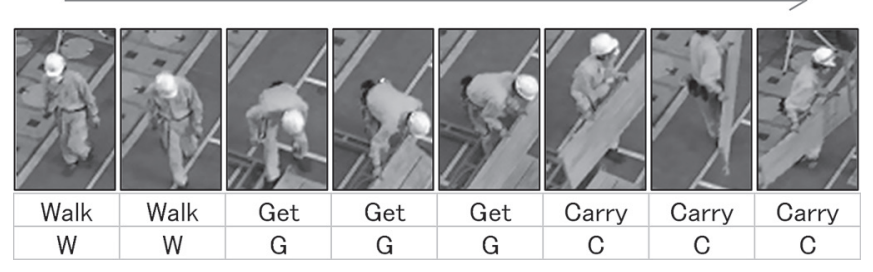

Fig. 2 Action Array $(1 \mathrm{~Hz})$

現実世界において連続している動作を, 等間隔に離散化して記録 
する。図中の事例では, 歩行 (Walk) が 2 測定点 (=2 秒), 持上 げ (Get) が 3 測定点 (=3 秒), 運搬 (Carry) が 3 測定点 (=3 秒）で記録された例を示している。

本論では, この動作分類を離散的に記録したデータを, その頭文 字をつなげた配列データとして取り扱うことを提案する。この配列 データを本論では「動作配列 (Action Array)」と呼称する。

図 2 の下段に示したとおり，この例においては「WWGGGCCC」 という動作配列が記録される。

動作配列の特徵は, 時間に関する情報が配列における文字数とし て記録される点にあり，これは動作分類と当該動作の経過時間を 1 対のデータで記録する既往のメモモーション手法とは異なる。

著者は動作手順の観測を動作配列データの記録として実施するこ との利点が，ICT による自動測定との相性の良さにあると考える。 等間隔の離散データ取得はセンサ計測が基本とする記録方法である ため, 将来的な測定法の発展を視野に入れ, 動作配列化を起点とす る分析を志向する。

\section{3 動作配列の取り扱い}

建築作業者の動作を連続して記録する動作配列は長大となること が想定されるため, そのデータ利用には工夫が必要となる。

著者は長大な文字列のデータの活用法を調査する中で, 遺伝子研 究分野における手法が，動作配列の活用に効果的であると考える。

当該分野は, 2003 年に約 30 億文字のヒトの全 DNA 塩基配列が 解明され, データベースの整備が進むとともに，その分析手法も発 展しており，詳細な解説は参考文献 11）をご覧いただきたいが，長 大な文字列のサンプルを収集し，その類似部分や非類似部分を特定 し，サンプルが発現している特性との関係性を分析することで，長 大な文字列中の価值ある部分とその機能を特定する研究分野である。

著者は当該分野で明らかにされた遺伝子情報の “転写・翻訳” の プロセス（セントラルドグマ）が，建築生産における実積データを 標準化するプロセスと共通する概念であると考える。

すなわち, シンプルな 4 種の文字により記載された遺伝子（う設 計情報）が転写を繰り返す中で必要な部分のみに限定され, 複雑な 分子構造を持つタンパク質（う観測される実態）に翻訳される, と いうプロセスを逆に読み, 動作配列データをシンプルなデータに翻 訳・転写することで，全体系としての作業を分析・評価する手法を 検討していきたい。

\section{4 動作手順の抽出}

記録された動作配列は, テキストが動作分類の情報を持ち，その 文字数が時間に関する情報を持っている。手順を評価する上では, 動作の先行後続関係に着目するために, 時間情報を除去することで 動作手順のみに圧縮する必要がある。時間情報の除去により, 取付 時間の異なる複数の部品を取り扱う作業においても, 運搬作業の手 順に着目した評価を行うことが可能となる。

はじめに動作配列の持つ時間情報について考察する。動作配列に おいては，連続して記録されているテキストの文字数を継続時間と 捉えることは前述したが，動作分類の内，停滞（Stop）を時間情報 と捉えるべき場合も存在する。それは, 停滞が作業者自身が想定し た動作手順には含まれておらず，実施環境との調整によって発生す る時間の遅延であるためである。

すなわち，手順分析の目的が “作業者が想定した動作手順”の分
析にある場合には, 停滞を時間の遅延と捉えて除去の対象とし, 手 順分析の目的が “測定された動作手順” の分析にある場合には, 停 滞を動作として捉えて除去の対象としない。

上記の通り, 分析目的に応じた停滞の取り扱いに留意しながら, 動作配列の圧縮は連続した文字を一文字に縮約することでおこなう。 なお，停滞を示す “S” の除去は文字の縮約の前に実施し，前の 動作の継続として捉えて, 一つ前の動作分類で上書くこととする。

\section{5 繰り返し発生する動作手順}

本手法においては, 動作分類を 9 種類に単純化している。そのた め, 動作手順の調整がなく円滑に実施されている場合には, 図 1 で 示した位置変化と姿勢変化が滞ることなく実施されるため, 作業者 の動作は歩行（Walk）に始まり持上げ(Get)・運搬(Carry)して設置 (Place)する, などの基本的な動作のユニットを繰り返すかたちで観 測されることになる。この基本的な動作のユニットは，圧縮された 動作配列上に定型文（上記の例では “WGCP”）として繰り返し確 認されることになる。本研究においてはこの定型文を,「動作セット

(Action Set)」と呼称する。

動作セットは, 建築作業における一般的な状態変化の連続を想定 することで, 表 2 に示す 7 種の基本形に分類された。

Table2 Action Set

\begin{tabular}{|c|c|c|c|}
\hline No. & $\begin{array}{c}\text { Name of } \\
\text { Action Set } \\
\text { 動作セット名 }\end{array}$ & $\begin{array}{c}\text { Action } \\
\text { Set }\end{array}$ & $\begin{array}{l}\text { Outline } \\
\text { 概要 }\end{array}$ \\
\hline 1 & $\begin{array}{l}\text { Serve } \\
\text { 小運搬 }\end{array}$ & WGCP & $\begin{array}{l}\text { Walk-Get-Carry-Place } \\
\text { 目的とする対象物にアプローチし, 把 } \\
\text { 持し, 目的地に運搬し, 設置する動作 }\end{array}$ \\
\hline 2 & $\begin{array}{l}\text { Attach } \\
\text { 取付け }\end{array}$ & WGCI & $\begin{array}{l}\text { Walk-Get-Carry-Insert } \\
\text { 目的とする対象物にアプローチし, 把 } \\
\text { 持し, 当該対象物の完成位置に運搬 } \\
\text { し, 取り付ける動作 }\end{array}$ \\
\hline 3 & $\begin{array}{l}\text { Detach } \\
\text { 取外L }\end{array}$ & $\mathrm{WRCP}$ & $\begin{array}{l}\text { Walk-Remove-Carry-Place } \\
\text { 目的とする完成物にアプローチし，取 } \\
\text { 外し, 目的地に運搬し, 設置する動作 }\end{array}$ \\
\hline 4 & $\begin{array}{l}\text { Check1 } \\
\text { 手元確認 }\end{array}$ & WGKP & $\begin{array}{l}\text { Walk-Get-KAKUNIN-Place } \\
\text { 目的とする対象物にアプローチし, 把 } \\
\text { 持し, 検査等を実施し, 配置する動作 }\end{array}$ \\
\hline 5 & $\begin{array}{l}\text { Check2 } \\
\text { 対面確認 }\end{array}$ & WK & $\begin{array}{l}\text { Walk-KAKUNIN } \\
\text { 目的とする対象物にアプローチし，把 } \\
\text { 持せずに，検査等を実施する動作 }\end{array}$ \\
\hline 6 & $\begin{array}{c}\text { Craft1 } \\
\text { 手元加工 }\end{array}$ & WGAP & $\begin{array}{l}\text { Walk-Get-Arts-Place } \\
\text { 目的とする対象物にアプローチし，把 } \\
\text { 持し, 加工し, 設置する動作 }\end{array}$ \\
\hline 7 & $\begin{array}{c}\text { Craft2 } \\
\text { 対面加工 }\end{array}$ & WA & \begin{tabular}{|l|} 
Walk-Arts \\
目的とする対象物にアプローチし, 把 \\
持せずに，加工する動作
\end{tabular} \\
\hline
\end{tabular}

Table3 Partially missed forms of Action Set

\begin{tabular}{|c|c|c|c|}
\hline No. & $\begin{array}{c}\text { Base } \\
\text { form } \\
\text { 基本形 }\end{array}$ & $\begin{array}{c}\text { Partially missed form1 } \\
\text { (by short distance) } \\
\text { 欠落型(1) (位置変化微小) }\end{array}$ & $\begin{array}{c}\text { Partially missed form2 } \\
\text { (by light weight) } \\
\text { 久落型(2) (対象物軽量) }\end{array}$ \\
\hline 1 & WGCP & GCP, WGP, GP & WCP, WGC, WC \\
\hline 2 & WGCI & GCI, WGI, GI & WCI \\
\hline 3 & WRCP & RCP,WRP, RP & WRC \\
\hline 4 & WGKP & GKP & WKP, WGK \\
\hline 5 & WK & K & WAP, WGA \\
\hline 6 & WGAP & GAP & - \\
\hline 7 & WA & A & \\
\hline
\end{tabular}

また, 下記 2 つ条件においては表 3 に示す欠落型となることが 
想定される。

（条件 I ）位置変化微小による歩行／運搬の未検出

（条件 II）対象物軽量による持上げ／設置の未検出

\section{5. 動作手順の評価方法}

\section{1 円滑度の計算方法}

動作手順を評価する指標の一つとして“円滑度（Smoothness）” を提案する。順調な流れで実施されているか否かの指標であり, 評 価対象となる作業者あるいはその周囲の状況を知る上で重要な要素 となると考える。本論における “円滑”とは手順がルーチン化して 繰り返し実施されている状況を指すものである。

手順の円滑度は，圧縮された動作配列の長さに対する動作セット の占有率として式(1)の通り定義する。

$$
R_{\text {smoothness }}=\frac{\sum l_{\text {action set }(i)}}{L_{\text {compressed action array }}}
$$

動作配列が全て動作セットにより構成されている場合を最も円滑 な手順とし，その場合，円滑度は1.0 を示す。

円滑度の計算は観測された動作手順の評価を目的とするため, 動 作配列の圧縮においては，停滞“S”を除去しない。

圧縮された動作配列に対して, 動作セットを長さの順（4 文字 $\rightarrow 3$ 文字 $\rightarrow 2$ 文字 $\rightarrow 1$ 文字) に検索を掛け，重複のないように動作セッ 卜の合計文字数を計算し，圧縮された動作配列長で除算することで 円滑度の数值を取得する。なお，得られた動作セットの種類と数を 集計寸れば，得られた円滑度の值とあわせて動作の振り返りに使用 できる。円滑度の計算と同時に集計し記録することが望ましい。

\section{2 類似度の計算方法}

動作手順を評価する指標の一つとして “類似度（Similarity）”を 提案する。手順を改善していく上では，長時間の作業を記録した複 数の長大な動作配列から, 似通ったあるいは全く異なる作業手順と なったタイミングを抽出し, 改善の検討対象を絞り込むことが重要 であるためである。

類似度には 2 つの使用方法があると考える。一つは圧縮した動作 配列同士の全体の類似度を計算し，動作手順全体の傾向を把握寸る 方法であり，もう一つは圧縮した動作配列を部分的な短い動作配列 として走查しながら類似度を計算し, 繰り返し手順の発生位置と傾 向を把握する方法である。

類似度計算には, 長さの異なる文字列同士の距離計算においても 対応できる編集距離の計算手法であるレーベンシュタイン距離注 4) の計算手法を用いる。

2 つの圧縮された動作配列の類似度は，比較する文字列同士のレ 一ベンシュタイン距離を，2つの圧縮された動作配列の平均の長さ で除算した值として式(2)の通り定義する。

$$
R_{\text {similarity }}=\frac{L_{\text {levenshtein }}\left(\text { Com.a.a. }{ }_{\cdot i}, \text { Com.a.a.j }\right)}{\left(L_{\text {com.a.a. } \cdot i}+L_{\text {com.a.a.j }}\right) / 2} \quad \cdot \cdot(2)
$$

平均長で除算するのは, 複数の類似度を比較する際を考慮してい る。すなわち, レーベンシュタイン距離が 10 として計算された場
合に，それが平均長 100 の場合と 1000 の場合とでは類似の度合が 異なるため, 平均長で除算することで類似度の大小という要素を含 めることを目的としている。なお，二つの文字列が完全に一致しな い場合には編集距離は両者の文字数の合計（片方を全文字削除十他 方を全文字入力）となるため, 類似度は完全に不一致の際に最大值 2.0 を示す。類似度計算は, 作業条件に対して作業者が想定した動 作手順の差異を分析することに主眼を置くため, 動作配列の圧縮に おいては，停滞“S”を除去することとする。

\section{6. 枠組足場作業への適用}

\section{1 施工実験の概要}

前述した手法を検証するため, 円滑度と類似度の計算による動作 手順の評価手法を枠組足場施工実験における作業に適用した。

試験体は, $1200 \mathrm{~mm}$ 幅・1700mm 高の 2 段 2 スパンの枠組足場試 験体とした。外観ならびに施工ステップを図 3 に示す。実施場所は 弊社実験施設内とし, 平坦な床に測定の際のデータ確認を目的に $1 \mathrm{~m}$ 幅のグリッドを表示した。実験スペースの外観を図 4 に示す。

被験者は 4 名とし, 習熟による值の変動を抑えるため, 当該実験 環境において日常的に仮設足場工事を実施する業者に所属し, 仮設 足場にも実験場にも精通寸る作業者とした。実験実施にあたり収集 した被験者データを表 4 に示す。被験者は 30 代から 50 代の男性で あり, 足場工事に従事して 5 年以上の経験を持つ熟練工である。
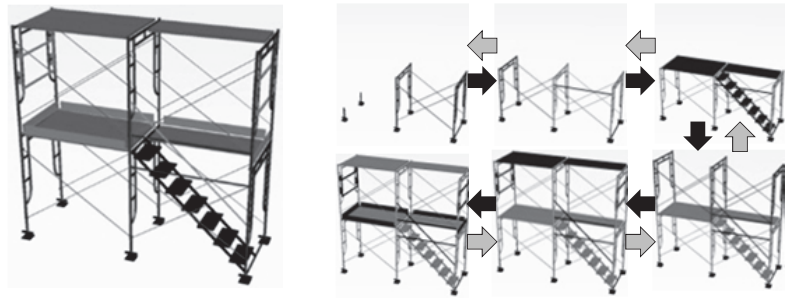

Fig. 3 Test piece of the experimental construction

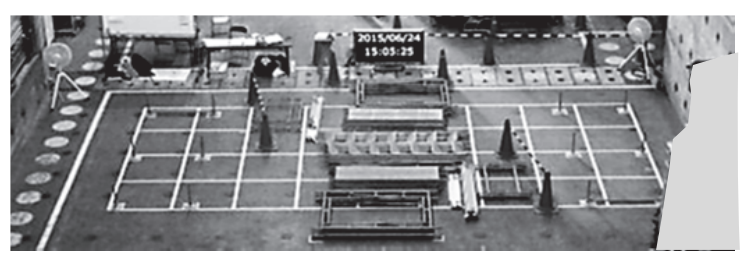

Fig. 4 The field of the experimental construction

\begin{tabular}{|c|c|c|c|c|c|c|c|c|c|c|}
\hline \multirow{3}{*}{ ID } & \multirow{3}{*}{\begin{tabular}{|l} 
年齢合 \\
age
\end{tabular}} & \multirow{3}{*}{$\begin{array}{c}\text { 勤続年 } \\
\text { Duration } \\
\text { [year] }\end{array}$} & \multirow{3}{*}{$\begin{array}{c}\text { 申告身長 } \\
\text { R.Height } \\
{[\mathrm{cm}]}\end{array}$} & \multirow{3}{*}{$\begin{array}{c}\text { 着靴身長 } \\
\text { M.Height } \\
{[\mathrm{cm}]}\end{array}$} & \multirow{3}{*}{$\begin{array}{c}\text { 申告体重 } \\
\text { R.Weight } \\
\text { [kg] }\end{array}$} & \multirow{3}{*}{$\begin{array}{c}\text { 着衣体重 } \\
\text { M.Weight } \\
{[\mathrm{kg}]}\end{array}$} & \multicolumn{4}{|c|}{ 握力 G rip Strength $(\mathrm{L} / \mathrm{R})[\mathrm{kg}]$} \\
\hline & & & & & & & \multicolumn{2}{|c|}{ 1st day } & \multicolumn{2}{|c|}{ 2nd day } \\
\hline & & & & & & & Morning & Finish & Morning & Finish \\
\hline A & $50 \mathrm{~s}$ & 15 & 165 & 166.3 & 62 & 62.85 & $46 / 44$ & $45 / 44$ & $40 / 41$ & $45 / 44$ \\
\hline $\mathrm{B}$ & $40 \mathrm{~s}$ & 15 & 182 & 18 & 57 & & $34 / 34$ & $31 / 32$ & $30 / 36$ & $32 / 34$ \\
\hline $\mathrm{C}$ & $50 \mathrm{~s}$ & 25 & 1 & & & & $30 / 39$ & $30 / 38$ & & $26 / 35$ \\
\hline $\mathrm{D}$ & $30 \mathrm{~s}$ & 5 & 165 & 167.1 & 60 & 62.35 & $43 / 46$ & $50 / 53$ & $43 / 49$ & $50 / 52$ \\
\hline
\end{tabular}

Table4 Data of research participants

実験は 2 日間で実施し, 1 日目に 1 人作業による組立作業と解体 作業を実施し, 2 日目に 2 人作業による組立作業と解体作業を実施 した。組立作業と解体作業の間には 5 分以上の小休止を挟みながら, 1 人作業は各被験者に組立作業と解体作業を計 10 作業, 2 人の組作 業は各組計 12 作業を実施させ, 各被験者に 22 作業, 4 名で延べ 88 作業を実施させた。作業は 2 か所での同時実施としたため, 1 人作 
業の際には残り 2 名は待機の状態となり, 2 人作業の繰り返しの際 よりも長い休㕷時間が与えられた。

1 人作業は, 各作業とも $\mathrm{A}$ と $\mathrm{B}$ の同時実施, $\mathrm{C}$ と D の同時実施を 繰り返すかたちでおこなった。2人の組作業は, ペアを固定 (A と $\mathrm{B} ， \mathrm{C}$ と D のペア）とし，2段目に上がることを片方の被験者のみ （B と D）とするよう制約を設けた。 2 段目に上がる被験者を段上 作業担当者, 上がらない被験者を段下作業担当者と呼称する。

実験時の温湿度は $25^{\circ} \mathrm{C} 65 \%$ 前後で推移した。熱中症などによる作 業速度低下は無いと仮定し, データを取り扱う。

\section{2 仮置きによる動作の省略}

作業の進捗において特筆す心゙き事象として「仮置きによる動作の 省略」が観察された。写真 1 は 1 段目の最初の建枠は不安定のため, 事前に筋かいを足元に仮置きすることで, 建枠を把持しながら筋か いを取付ける様子である。写真 2 は, 2 段目の構築時には筋かい等 の棒材をまとめて段上に仮置きすることで昇降のための歩行動作を 省略する様子である。2人作業の場合にもこれらの仮置きは積極的 に実施されており，作業位置近傍に部材を準備することで後続の動 作を省略する工夫が被験者に定着している様子が観察された。

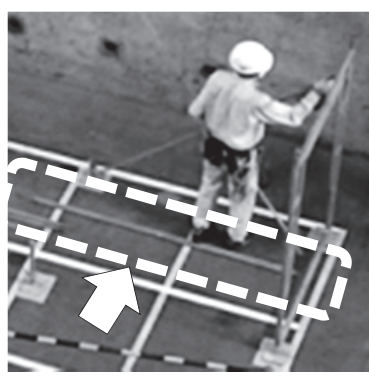

Photo1 Storage situation 1

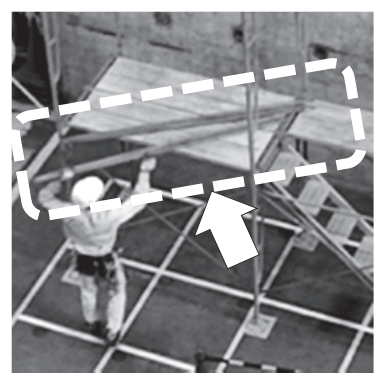

Photo2 Storage situation 2

\section{3 データ化作業}

データ化は, 既報 ${ }^{1)}$ において示したデータ化作業用システムを用 いて，以下に示すプロセスにおいてデータ化作業をおこなった。

・施工実験で得られた俯瞰位置からの動画ならびにカメラパラメ ータファイルをシステムに読込む

・動画から 1 秒毎のフレーム画像が画面に表示される

- 画像中の被験者位置(足元) と高さ情報をクリックで指定する (内部処理によって作業者の XYZ 座標を計算)

・ポップアップボタンから動作分類注 5), 部材分類等を選択する

・上記のデータと, 選択した内容を追記した画像が保存される

・以上のプロセスを分析対象期間分の画像に実施することで, 最 終的に, いつ $($ 時刻 $) \cdot$ 誰が (被験者 ID) ・ ゙こで $(\mathrm{XYZ}$ 座標)・何 をしたか（動作分類・部材分類），を 1 行とした時系列（1 秒間隔） のデータとして出力される。

得られたデータから, 動作分類の頭文字を読み取ることで動作配 列データを作成した。

\section{4 作業終了時間と動作構成}

組立作業ならびに解体作業の各回は, 表 5 に示寸作業終了時間に より実施された。横軸に繰返し回数, 縦軸を作業終了時間としたグ ラフを図 5 に示寸。休䅛をはさんだ前後での実施であった点が影響 したと思われる作業時間の変動が複数見受けられる。
1 人作業（solo-Attach, solo-Detach）においてはおおよそ 10 分 程度であった作業が, 2 人作業とすることで 5 分程度での完了とな っている。作業時間の変化に関する考察は本論では割愛する。

本事例における全作業を合計した場合の動作構成を図 6 に示す。 図は圧縮前の動作配列の文字数と, 圧縮された動作配列の文字数と を集計した結果である。すなわち前者は動作時間構成を示し, 後者 は時間情報を除いた動作手順上の発生数構成を示す。円グラフの周 囲は 9 動作の比率を示し, 中央には加工系の 3 種（取付け I ・取外 L R ・ 加工 A） と, 運搬系の 4 種（歩行 $\mathrm{W} \cdot$ 持上げ $\mathrm{G} \cdot$ 運搬 $\mathrm{C} \cdot$ 設 置 P）とを合わせた比率を示した。本事例においては, 作業時間の 過半が運搬系動作に使用されているとともに, 動作発生数の 8 割は 運搬系動作と停滞により占められている。作業時間という視点にお いても, 時間情報を除いた動作手順という視点においても, 運搬系 動作と停滞との影響が大きいことが明らかになった。

Table5 Finish time [h:mm:Ss]
\begin{tabular}{|c|c|c|c|c|}
\hline $\begin{array}{c}\text { Solo } \\
\text { Attach }\end{array}$ & A & B & C & D \\
\hline case1 & $0: 16: 27$ & $0: 15: 08$ & $0: 16: 47$ & $0: 15: 37$ \\
\hline case2 & $0: 15: 16$ & $0: 13: 05$ & $0: 15: 57$ & $0: 12: 33$ \\
\hline case3 & $0: 16: 18$ & $0: 16: 17$ & $0: 16: 09$ & $0: 11: 10$ \\
\hline case4 & $0: 14: 54$ & $0: 12: 54$ & $0: 13: 49$ & $0: 13: 31$ \\
\hline case5 & $0: 14: 29$ & $0: 12: 41$ & $0: 12: 23$ & $0: 10: 06$ \\
\hline $\begin{array}{c}\text { Solo } \\
\text { Detach }\end{array}$ & A & B & C & D \\
\hline case1 & $0: 12: 52$ & $0: 12: 34$ & $0: 14: 00$ & $0: 13: 34$ \\
\hline case2 & $0: 13: 46$ & $0: 12: 10$ & $0: 12: 27$ & $0: 12: 02$ \\
\hline case3 & $0: 13: 30$ & $0: 11: 32$ & $0: 11: 57$ & $0: 11: 23$ \\
\hline case4 & $0: 11: 24$ & $0: 11: 20$ & $0: 11: 20$ & $0: 11: 08$ \\
\hline case5 & $0: 10: 29$ & $0: 10: 41$ & $0: 11: 11$ & $0: 08: 31$ \\
\hline Pair & A \& B & C \&D & A \& B & C \&D \\
Work & Attach & Attach & Detach & Detach \\
\hline case1 & $0: 06: 41$ & $0: 07: 08$ & $0: 05: 04$ & $0: 05: 44$ \\
\hline case2 & $0: 06: 55$ & $0: 06: 25$ & $0: 05: 15$ & $0: 05: 09$ \\
\hline case3 & $0: 07: 42$ & $0: 06: 50$ & $0: 05: 21$ & $0: 04: 56$ \\
\hline case4 & $0: 07: 20$ & $0: 07: 02$ & $0: 05: 10$ & $0: 05: 22$ \\
\hline case5 & $0: 07: 18$ & $0: 06: 18$ & $0: 05: 12$ & $0: 05: 07$ \\
\hline case6 & $0: 07: 13$ & $0: 06: 15$ & $0: 05: 26$ & $0: 05: 25$ \\
\hline
\end{tabular}

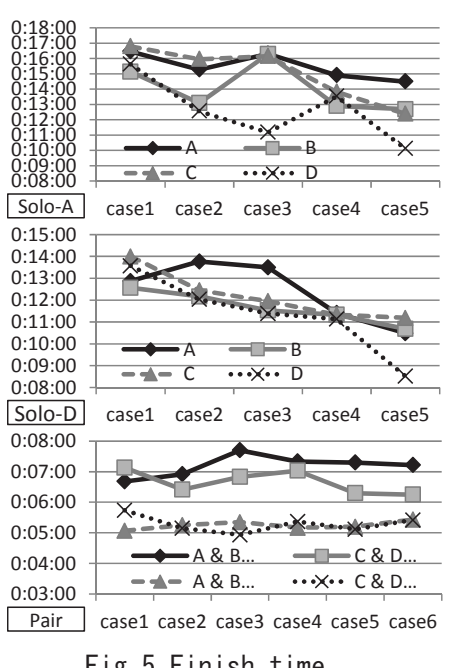

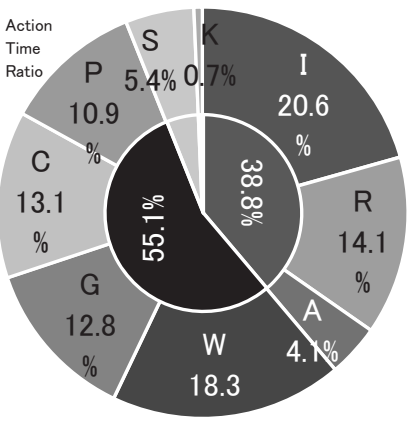

a) Action Array

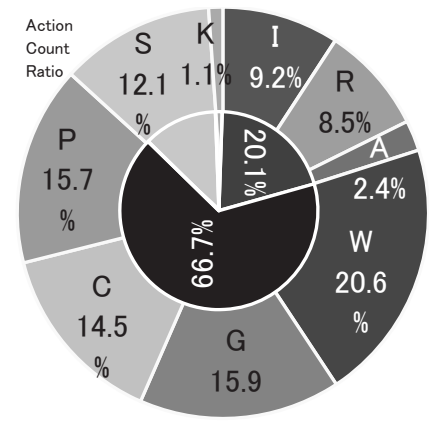

b) Compressed Action Array
Fig. 6 Component ratio of action category (1)

\section{5 円滑度による作業の評価 \\ 6.5.1 円滑度の計算}

前章の計算方法に従って, 各回の円滑度を求めた。結果を表 6 な らびに図 7 に示す。

1 人作業における円滑度は, 組立作業と解体作業双方で, $0.7 \sim 0.9$ の間の值が得られた。組立作業の被験者 $\mathrm{C}$ と D は は, 前述した作業 時間とは逆の動きのグラフが得られている。すなわち作業時間の短 縮と円滑度の向上に相関がある事例が得られた。 
2 人作業における円滑度は，おおよそ $0.6 \sim 0.85$ の間の值が得ら れた。被験者 $\mathrm{A}$ の 3 回目は最低值の 0.5 を示した。総じて 1 人作業 に比べて低い円滑度となる傾向と言える。動作配列に戻り原因を観 察したところ，停滞（Stop）の発生が各所で発見された。2 人作業 における手待ちの発生が, 円滑度の低下として顕在化した。

本事例の円滑度の平均は約 0.78 であり,すなわち動作手順上の約 $12 \%$ 動作が動作セットに該当しなかった。それぞれの構成を図 8 に示す。動作セットに該当しない動作の 57 。2\%は停滞 S であった。

停滞以外の動作は，停滞により分断された動作である場合が多い （例えばWSWや，ISI など）。停滞に依らない例として，手戻りの 発生が RCI（取外し・運搬・取付け）として検出された。

\begin{tabular}{|c|c|c|c|c|}
\hline $\begin{array}{l}\text { Solo } \\
\text { Attach }\end{array}$ & A & B & C & D \\
\hline case1 & 0.76 & 0.83 & 0.76 & 0.77 \\
\hline case2 & 0.83 & 0.89 & 0.80 & 0.85 \\
\hline case3 & 0.73 & 0.74 & 0.83 & 0.89 \\
\hline case4 & 0.72 & 0.87 & 0.85 & 0.81 \\
\hline case5 & 0.72 & 0.90 & 0.87 & 0.90 \\
\hline $\begin{array}{l}\text { Solo } \\
\text { Detach }\end{array}$ & A & B & C & D \\
\hline casel & 0.79 & 0.82 & 0.77 & 0.79 \\
\hline case2 2 & 0.76 & 0.84 & 0.86 & 0.84 \\
\hline case3 & 0.73 & 0.89 & 0.84 & 0.82 \\
\hline case4 & 0.76 & 0.84 & 0.89 & 0.79 \\
\hline case5 & 0.79 & 0.86 & 0.81 & 0.84 \\
\hline $\begin{array}{c}\text { Pair } \\
\text { Attach }\end{array}$ & A & B & C & D \\
\hline casel & 0.68 & 0.72 & 0.81 & 0.71 \\
\hline case2 & 0.64 & 0.81 & 0.79 & 0.69 \\
\hline case3 & 0.50 & 0.72 & 0.74 & 0.76 \\
\hline case4 & 0.64 & 0.71 & 0.69 & 0.70 \\
\hline case5 & 0.66 & 0.72 & 0.78 & 0.73 \\
\hline case6 & 0.66 & 0.70 & 0.72 & 0.75 \\
\hline $\begin{array}{l}\text { Pair } \\
\text { Detach }\end{array}$ & A & B & C & D \\
\hline casel & 0.80 & 0.86 & 0.70 & 0.71 \\
\hline case2 2 & 0.70 & 0.83 & 0.81 & 0.78 \\
\hline case3 & 0.72 & 0.85 & 0.74 & 0.82 \\
\hline case4 & 0.73 & 0.82 & 0.75 & 0.74 \\
\hline case5 & 0.65 & 0.73 & 0.72 & 0.76 \\
\hline & 0.63 & 0.82 & 0.79 & 0.80 \\
\hline
\end{tabular}

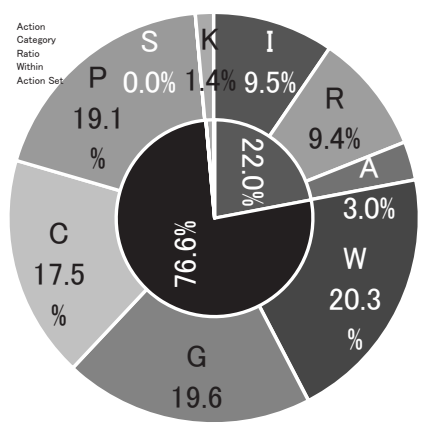

a) Action Set

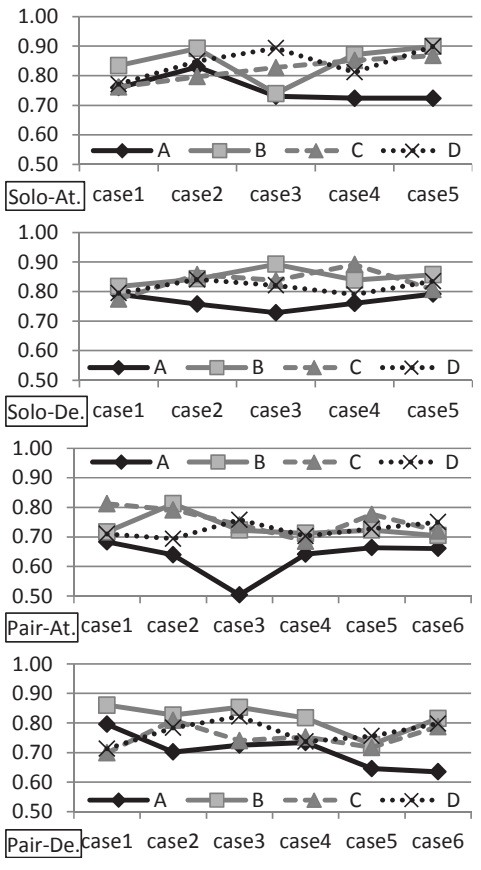

Fig. 7 Smoothness

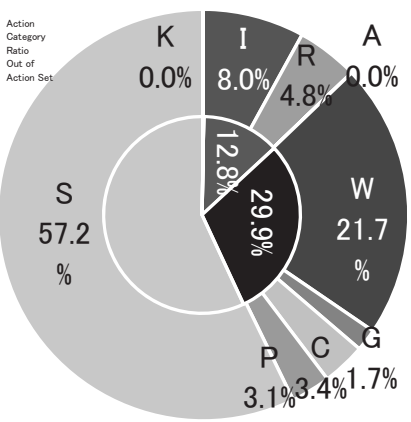

b) Out of Action Set
Fig. 8 Component ratio of action category (2)

円滑度の計算と共に，動作セットの集計を実施した。結果の一例 として, 被験者 $\mathrm{A}$ と B の 1 人作業と 2 人作業それぞれにおいて 3 回目のデータを円グラフとした。結果を図 9 に示す。

図 9 上段の 2 つの円グラフは被験者 $\mathrm{A}$ と被験者 $\mathrm{B}$ の 1 人作業 3 回目の実施時における動作セットの構成比率である。被験者 $\mathrm{A}$ は被 験者 B に比べて検出された動作セットの種類が多く, WGK, WK
など確認に関連する動作セットがある。なお，作業時間は被験者 $\mathrm{A}$ が 16 分 18 秒, 被験者 B が 16 分 17 秒と差はなく, 円滑度も被験 者 $\mathrm{A}$ が 0.73，被験者 $\mathrm{B}$ が 0.74 と差がない。

図 9 中段の 2 つの円グラフは A と B がペアとなって実施した 2 人の組作業の 3 回目の実施時における動作セットの構成比率である。 段下での運搬を担当した $\mathrm{A}$ と段上での取付を担当した B とでは構成 比率に大きく差が現れた。いずれも担当に応じた動作セットの比率 が高くなっている。また, 図 9 下段の円グラフは, 中段の 2 つの円 グラフを統合した構成比率を示している。これを見ると， 2 人作業 の場合の構成比率と構成数とが, 1 人作業の場合の構成比率と構成 数とほとんど変化していないことが読み取れる。
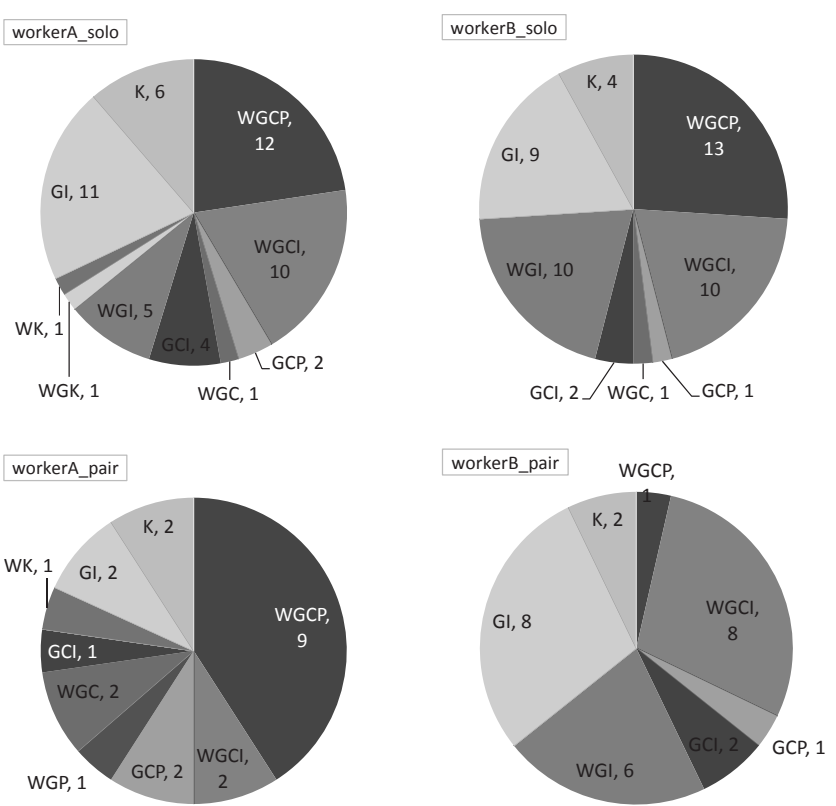

sum_pairA\&B

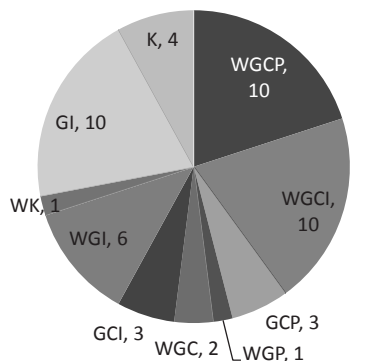

\begin{tabular}{|lll|}
\hline I $:$ Insert & 取付け \\
R : Remove & 取外し \\
A : Arts & 加工 \\
W : Walk & 歩行 \\
G : Get & 持上げ \\
C : Carry & 運搬 \\
P : Place & 設置 \\
S : Stay & 停滞 \\
K : KAKUNIN & 確認 \\
\hline
\end{tabular}

Fig. 9 Component ratio of Action Set

\subsection{2 円滑度に関する考察}

本論で提案した円滑度の効果を考察する。図 6 と図 8 の動作構成 に示したとおり, 円滑度を低下させる主たる要因は動作手順上の停 滞 “S”の発生であった。そこで停滞の発生状況を, 圧縮された動 作配列上で観察すると, 停滞が動作セットと動作セットの間で発生 している場合と, 動作セット内で動作セットを分割するように発生 している場合とがあることが明らかとなった。前者は停滞を示す“S” 1 文字が円滑度を低下させるが, 後者は分割された動作セットの文 
字も円滑度を低下させることになり，すなわち動作手順中の停滞の 発生タイミングの影響の多少を評価する効果があるといえる。これ は単なる動作分類のみで評価するのではなく, 動作セットを定義し て円滑度を計算する本論の手法の効果である。

図 9 の事例においては，1 人作業における構成比率と構成数が保 存されたまま 2 人作業における個々の作業者に分割されていること が確認された。施工実験特有の現象であるか否かは今後, 事例を収 集し一般化に向けて考察を進めたい。

\section{6 類似度による作業の評価}

\section{6.1 類似度の計算}

前章の計算方法に従って, 各回の動作配列全体を用いて類似度を 計算した。6.1 に示した通り, 延べ 88 作業の 88 個の動作配列があ り，総当たりで計算して 3916 個の類似度の值を得た。結果を図 10 に示す。

図は横軸と縦軸にそれぞれ動作配列に付与した ID を記載してい る。ID は「被験者 ID (a/b/c/d) ）組立作業か解体作業か (A/B) +1 人作業か 2 人作業か ( solo/pair) +繰返し回数 $(01 \sim 06) 」$ と して定義し付与した。マトリックス上の交差位置には，それぞれ該 当する 2 つの動作配列同士の類似度を記載した。

図中の色は, 図の右上の凡例に示した通り，白塗りに黒文字が手 順が類似したペアを表し，黒塗りに白文字となるほど手順が類似し ないペアを示している。図の左下から右上への対角線は同一の動作 配列の類似度であり, 類似度 $=0.00$ すなわち完全一致している。

図中の階段状の凡例に示した通り，実験条件の特性の組み合わせ から，下記の(1)〜(10)のエリアに分類ができる。

（1） 1 人作業組立と 1 人作業組立の比較

(2) 1 人作業解体と 1 人作業解体の比較

(3) 2 人作業組立と 2 人作業組立の比較

（4） 2 人作業解体と 2 人作業解体の比較

（5） 1 人作業組立と 1 人作業解体の比較

（6） 1 人作業解体と 2 人作業組立の比較

（7） 2 人作業組立と 2 人作業解体の比較

(8) 1 人作業組立と 2 人作業組立の比較

（9） 1 人作業解体と 2 人作業解体の比較

（10） 1 人作業組立と 2 人作業解体の比較

図 10 のエリア(1)(2)とエリア(3)(4)の一部は同一作業の類似度で あり 0.08 0.49 を示した。エリア(3)(4)の他方は 2 人作業における 段上/段下で担当の違う動作配列の類似度であり $0.57 \sim 0.87$ を示し た。エリア(5)は 1 人作業における組立/解体の動作配列の類似度で あり 0.84 1.01 を示した。エリア(6)(10)は人数と組立/解体とのどち らも異なる動作配列の類似度であり 0.81 1.45を示した。エリア(7) は 2 人作業における組立/解体の動作配列の類似度であり, 段下担当 同士では 0.39 0.62, 段上担当同士では 1.22 1.53, 異なる担当同士 では 0.84 1.21 を示した。エリア (8)(9)は組立解体を共通とした人数 の異なる動作配列の類似度であり，0.53 0.91 を示した。

エリア(7)における段下担当同士の類似度は 0.50 以下の值も示し ており同一作業の類似度と同等の結果が読み取れる。これは 2 人作 業における段下の運搬担当の動作手順は, 組立作業と解体作業とで
類似するという結果である。

繰返し手順の発生傾向に関して, エリア (7)の被験者 $\mathrm{a}$ の 2 人作業 解体 4 回目 (aB-pair04) と被験者 $\mathrm{c} の 2$ 人作業組立 4 回目 (cA-pair04) とを比較した結果を図 11 に示す。比較は図 11 左側の拡大図にある 通り, $\mathrm{n}$ から $\mathrm{n}+11$ 文字目注6) とする部分配列を 1 文字目から順に 抽出（1～12 文字を配列 $1,2 \sim 13$ 文字を配列 $2, \cdots$ とする抽出）し， 総当たりで類似度計算を実施している。図 11 右側の全体図は左か ら右に被験者 $\mathrm{c} の 2$ 人作業組立 4 回目における圧縮した動作配列を 示し，上から下に被験者 $\mathrm{a}$ の 2 人作業解体 4 回目における圧縮した 動作配列を示している。図の左上から右下に向かった時系列となっ ており，白色となるほど類似していることをあらわす。

完全一致となる部分配列（この場合は WGCPWGCPWGCP を中 心にその変形）が確認されている。繰り返し動作は双方の手順の中 盤に発生していることが読み取れる。これは 2 人での組立作業の序 盤は段下作業担当者も取付娚作を実施し, 解体作業の終盤は段下 作業者も取外し動作を実施するため, 双方ともに運搬動作を専任す る中盤での夕類似するという事象であり，事実と整合している。

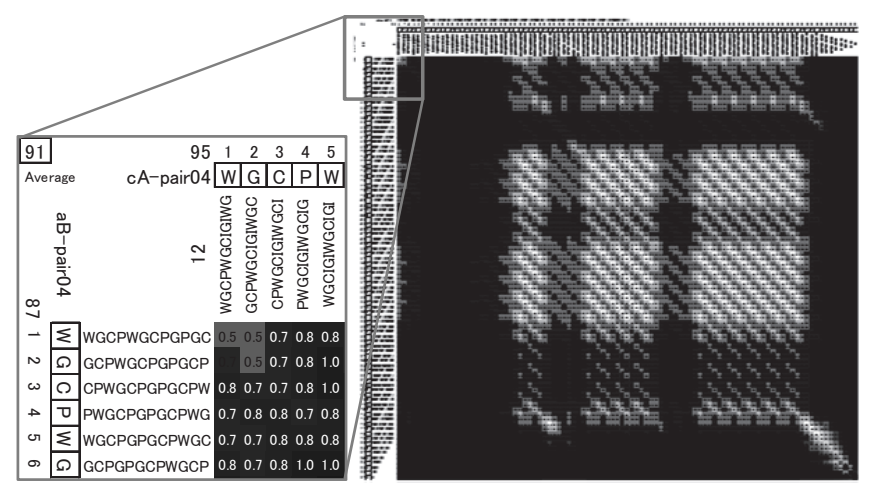

Fig. 11 Results of partial similarity calculation (12text)

\section{6.2 類似度に関する考察}

本事例は同一企業に所属し十分に業務経験のある作業者に, 同一 環境で同一工種の作業を実施させた場合の結果であり，技能の違 い・技能教育文化の違い・作業環境の違い. 一種の違い, に言及で きるものではないが, 組立と解体の違い. 1 人作業と 2 人作業によ る作業分担の違いに言及するものである。組立と解体の違いは, 動 作配列上には取付け“I”か取外し “R”のいずれが発生するかとい う違いであり, 作業分担の違いは, 取付け “I” と取外し “R” が段 上担当者の動作配列に集中し, 段下担当者の動作配列は運搬が大部 分を占めることになるという違いとして表出する。

前項の結果から, 本論で提案した類似度は, 取付け “I”と取外し “R”の相違により高い值となり，運搬作業の実施が多い場合に低 い值となる傾向があることが明らかとなった。

本研究における類似度計算は, 文字列の長さに応じて増加する性 質のある編集距離の影響を緩和する目的で, 比較する配列長の平均 で距離を除算することを特徵とする。類似度の最大值 1.53 が検出さ れたエリアが, 動作配列長が異なる 1 人作業と 2 人作業との比較 (エ リア(6),(8),(9),(10)）ではなく 2 人作業同士の比較（エリア(7)）に おいて検出されたことは, 平均距離による除算が効果を発揮してい るということであり，本論における定義の妥当性が示された。 


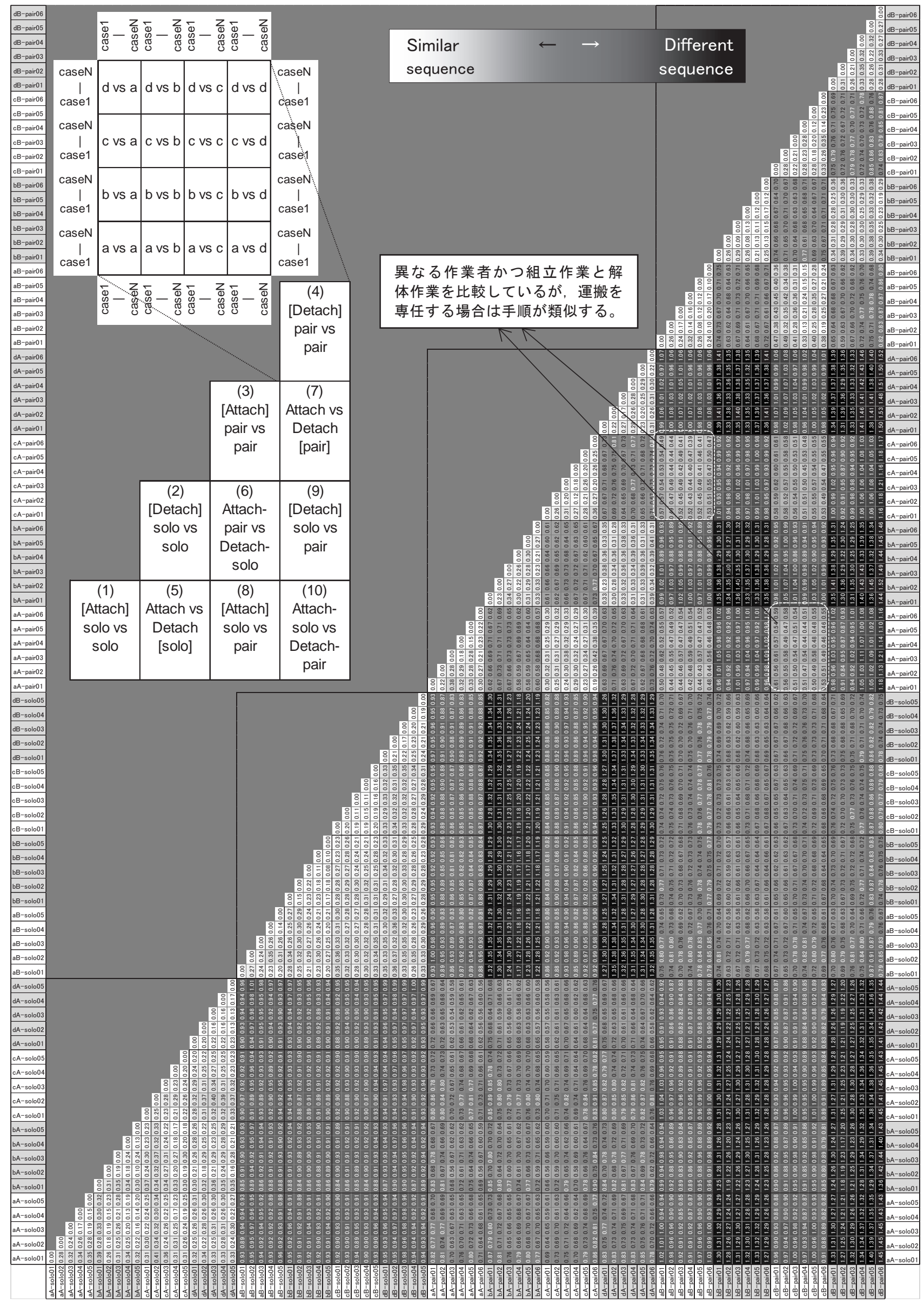

Fig. 10 Results of similarity calculation 
また, 2 人作業における段下の運搬担当の動作手順が, 組立と解 体で類似するというエリア(7)における結果は, 運搬を専任とするこ とにより, 運搬担当者の手順を統一寸る効果を表している。さらに 図 11 の通り, 動作配列の部分ごとに類似度を確認した例は, 複数 の手順において類似点と相違点の発生タイミングを定量的に取得で きた結果を示している。同図においては白色の領域が横長の形状を しており，すなわち横方向に配置した cA-Pair04の動作配列のほう が同一手順を繰り返す安定した流れといえる。改善の着眼点は, 図 中の黒色となった部分にあると考えられる。同一手順の繰り返しが 途切れた部分に着目し，他のデータを参照し原因を探る次の検討に 移ることが可能となる。類似度による手順評価の効果が示された。

\section{7. 結言}

本論においては, はじめに建築作業における動作の捉え方を再確 認し, 運搬動作の重要性に言及しながら, 本研究における動作分類 を定義した。次に, 動作手順の特徴について言及しながら, 本研究 における動作手順の記録手法として「動作配列」の考えを示した。 さらに動作配列を基にした手順の評価值として, 円滑度と類似度の 計算手法を提案した。最後に, 施工実験によるデータを用いて当該 手法を検証した。本研究により,これまでは勘と経験という主観的 評価に頼ってきた手順評価に新たな定量的な指標を提案した。今後 は, 当該手法を実際の建築現場の作業測定に適用することで, 建築 現場特有の手順の特性を定量的に明らかにしていく予定である。

\section{参考文献}

1) Hiroaki ISHIOKA: Interface System for Capturing Workers' 3D Paths in The Construction Processes, AIJ Journal of Technology and Design, Vol.21, No.49, pp.1269-1272, 2015.10 (in Japanese)

石岡宏晃：建築作業における運搬経路分析のための 3 次元座標取得インタ フェースシステムの開発, 日本建築学会技術報告集, Vol.21, No.49, pp.1269-1272, 2015.10

2) Yasushi TAMURA, et al.: Kenchikugenbasekounogourikanikansurukenkyu dai-ippo dousakeizainogensokushian (Study on retionalization of construction site work vol.1 Private ideas of principles of motion economy), Proceedings of AIJ Conference in Kanto chapter, vol.33, A45-A48, 1963.01 (in Japanese)

田村恭, ほか 4 名：建築現場施工の合理化に関する研究 第一報:動作経済 の原則私案, 日本建築学会関東支部学術研究発表会梗概集, 第 33 号, A45-A48, 1963.01

3) Recommended Practice for Method Improvement on Construction Work, AIJ, 1990 (in Japanese)

作業能率測定指針, 日本建築学会, 1990

4) Kjell B. Zandin: MOST; Work measurement systems (second edition, revised and expanded) (trans. by Shigeyasu SAKAMOTO), JMAC, 1993.06 (in Japanese)

シェル・B・サンディン: MOST 画期的な標準時間の設定法, 坂本重泰訳, 日本能率協会, 1993.06

5) Eguchi, A., Masamura, Y., Dobashi, T., Yoshida, T.: Creation of Time Standard for Building Work Based on MOST, Journal of Architecture, Planning and Environmental Engineering (Transactions of AIJ), AIJ, No.490, pp.135-144, 1996.12 (in Japanese)

江口敦士, 正村芳久, 土橋稔美, 吉田知洋: MOST 法による建築工事の標準 時間設定建築生産におけ括法法適用に関する研究, 日本建築学会計 画系論文集，第 490 号, pp.135-144, 1996.12

6) Mine, N., Takada H., Kunugi T.: Process Analysis of Interior Finishing and Building Services Works A Study of Housing Project Interior Finishing Works Part 1, Journal of Architecture, Planning and Environmental Engineering (Transactions of AIJ), No.534, pp.233-240,
2000.08 (in Japanese)

三根直人，高田博尾，椚隆：内装・設備工事の工程分析 集合住宅におけ る内装工事に関寸る研究 その 1 , 日本建築学会計画系論文集, 第 534 号, pp.233-240, 2000.08

7) Shide, K., Kanisawa, H., Ishida, S., Yuasa Y., Someya, S.: Research on Productivity of Interior Finish Work in High-rise Buildings Part 9 Outline of Search Procedure in Supply Chain of Interior Finish Work, Summaries of Technical Papers of Annual Meeting, Architectural Institute of Japan, F-1, pp.1289-1290, 2011.08 (in Japanese)

志手一哉, 蟹澤宏剛, 石田祥子, 湯浅洋一, 染谷俊介: 高層集合住宅におけ る内装仕上工事の生産性に関する研究 (その 9) 場内物流に関する考察, 日 本建築学会大会学術講演梗概集, F-1, pp.1289-1290, 2011.08

8) Takatsuji, K., Kanisawa H., Watanabe, C., Gondo, T., Tsunashima, A., Matsumura, S.: Productivity Improvement of Industrialized Detached Houses Part 1 Quantitative Analysis Based on the Man-hour Investigation, Summaries of Technical Papers of Annual Meeting, Architectural Institute of Japan, F-1, pp.147-148, 2015.09 (in Japanese)

高辻慶太, 蟹澤宏剛, 渡辺千晴, 権藤智之, 綱島淳, 松村秀一, 工業化工 法住宅の生産性向上に関する研究 その 1 工数調査に基づく定量的分析, 日本建築学会大会学術講演梗概集, F-1, pp.147-148, 2015.09

9) Watanabe, C., Gondo, T., Takatsuji, K., Kanisawa H., Tsunashima, A., Matsumura, S.: Productivity Improvement of Industrialized Detached Houses Part 2 Detecting Problems and Improving Construction Method, Summaries of Technical Papers of Annual Meeting, Architectural Institute of Japan, F-1, pp.149-150, 2015.09 (in Japanese)

渡辺千晴, 権藤智之, 高辻慶太, 蟹澤宏剛, 綱島淳, 松村秀一, 工業化工 法住宅の生産性向上に関する研究 その 2 作業における問題点・改良提 案，日本建築学会大会学術講演梗概集, F-1, pp.149-150, 2015.09

10)Yasushi TAMURA, et al., Kenchikugenbasekounogourikanikansuru kenkyu dai-niho saaburikkukigounoteian (Study on retionalization of construction site work vol.2 Proposition of therblig), Proceedings of AIJ Conference in Kanto chapter, vol.33, A49-A52, 1963-01 (in Japanese) 田村恭, 他 4 名, 建築現場施工の合理化に関する研究 第二報 : サーブリ ッグ記号の提案, 日本建築学会関東支部研究発表会梗概集, 第 33 号, A49-A52, 1963-01

11) Ikegami, M. and Ebihara, M.: Molecular Biology, Kodansya Ltd., 2013.11 (in Japanese)

池上正人・海老原充：分子生物学（第 2 版）新バイオテクノロジーテキス トシリーズ, 講談社, 2013.11

注

注 1 ) 全作業を主体作業・付帯作業・余裕・非作業と分ける分類は「作業能 率測定指針（日本建築学会 1990）」における定義による。

注 2 ) MOST 手法は, 基本となる BasicMOST のほか, 微小な時間の作業を 取扱う MiniMOSTと, 比較的長い作業を取り扱う MaxiMOSTとから成る。

注 3 ) 建築設計資料集成 - 人間（日本建築学会, 2003.1）のp.58 欄外, にお いて, 右足接地から次の右足接地までの時間を指寸歩行周期について『歩 行周期は正常人でほぼ $1 \mathrm{~Hz}$ である』としている。

注 4 ）レーベンシュタイン距離 : 一方の文字列を他方の文字列に書きなおす ために必要な「追記・削除・置換」の操作の回数により定義する。異なる 長さの文字にも対応できる。なお本研究においては「置換＝削除十追記」 ととらえ, 追記と削除にコ外 1 , 置換にコ外 2 を付与する。

例(1) : $\mathrm{ABCD}$ と $\mathrm{ACDB} \rightarrow 2(\mathrm{~B}$ 削除・ B 追加) 例(2): $\mathrm{ABCD}$ と $\mathrm{BCDA} \rightarrow 2(\mathrm{~A}$ 削除・ $\mathrm{A}$ 追加)

注 5 ) 動作分類においては下記の客観的判断ルールを設けた。

「前の画像から比較して建築作業者の足の位置が変化している場合を移動 と定義し, 移動中かつ保持部材有りの場合は“運搬”を付与。移動中かつ保 持部材無しの場合は“歩行”を付与。移動していない場合に, 空手から部材 を保持する一連の動作には“持上げ”を付与。逆の場合は“設置”を付与。部材 を完成位置に取り付ける動作である場合には“取付け”を付与。部材を完成 位置から取り外寸動作である場合には“取外し”を付与。何らかの動作が確 認できない場合には“停滞”を付与。前述のいずれの条件にも当てはまらな い動作には“確認”を付与。」

注 6 ) 複数の部分配列長による出力結果を比較し, 動作セット 3 つ分の 12 文字が, 今回例示した比較対象に対して傾向をよく表していると判断した。 


\section{ACTIVITY PROCESS ANALYZATION OF CONSTRUCTION WORKERS}

\section{Hiroaki ISHIOKA*}

* Institute of Technology, SHIMIZU Corp., M.Arch.

The author demonstrated a new evaluation method of construction workers' activity sequence.

Chapter 2 describes the previous works in the field of work study in Japan. Analyzes of activities at construction sites in Japan originally started in 1960s and these methods were compiled into "Recommended Practice for Method Improvement on Construction Work" (AIJ, 1990).

Chapter 3 describes the actions at construction sites. The sequence of construction can be regarded as the sum of the sequences of each parts transportation. So the author classified the worker action to nine categories, these are 'Insert', 'Remove', 'Arts', 'Walk', 'Get', 'Carry', 'Place', 'Stay', and 'KAKUNIN', based on the change of condition (e.g. rotation, position, shape, and finishing).

Chapter 4 describes the method to record action categories. The author describes new datasets named 'Action Array'. It is an array of capital letters of action categories which was captured in construction activity on $1 \mathrm{~Hz}$. The author focused on methods in genetics (e.g. transcription and translation in the Central dogma of molecular biology) for solving the problem on translation from capturing data to sequence information.

Chapter 5 explains the flow of calculation of 'Smoothness' of Action Array and 'Similarity' between pairs of Action Array. The proposed method needs compression of action array, which is a step for shorten consecutive letters. Smoothness is a ratio of sum length of 'Action Set' to the length of Compressed Action Array. Action Set means some words which are repeatedly shown in compressed action array. The author classified 7 standard types and 22 derivative types. Similarity is a ratio of the Levenshtein distance to the average length of pair of compressed action array.

$$
\begin{aligned}
& R_{\text {smoothness }}=\frac{\sum l_{\text {action set }(i)}}{L_{\text {compressed action array }}} \\
& R_{\text {similarity }}=\frac{L_{\text {levenshtein }}(\text { Com.a.a. } \cdot \text {, Com.a.a.j })}{\left(L_{\text {com.a.a. } \cdot i}+L_{\text {com.a.a.j }}\right) / 2}
\end{aligned}
$$

Chapter 6 presents the verification of the proposed method by test calculation using sample data which was captured in the experimental construction of scaffoldings. The author got 88 action arrays from the experimental construction and calculated 88 smoothness score and 3916 similarity score. Some results of analysis were shown in chapter 6 . 